Title of the article:

A male determinant gene in diploid dioecious Diospyros, OGI, is required for male flower production in monoecious individuals of Oriental persimmon (D. kaki)

5 Takashi Akagi ${ }^{1,2}$, Takashi Kawai ${ }^{1}$, and Ryutaro Tao ${ }^{{ }^{*}}$

1. Graduate School of Agriculture, Kyoto University, Kyoto 606-8502, Japan

2. PRESTO, JST, Saitama, Japan

*corresponding author (E-mail: rtao@kais.kyoto-u.ac.jp)

(C) 2016. This manuscript version is made available under the Elsevier user license http://www.elsevier.com/open-access/userlicense/1.0/ 


\begin{abstract}
The sexuality of crops is an important trait affecting production and breeding efficiencies. Recently, a Y-chromosome-encoded gene, designated Oppressor of MeGI $(O G I)$, has been shown to play a central role in dioecious sex determination in diploid persimmons (Diospyros spp.). However, little is known 15 about the relationship between $O G I$ and the irregular sexuality in polyploid persimmon (D. kaki). D. kaki, which is mostly hexaploid with some nonaploid individuals, is mainly constituted of monoecious and female individuals. In this study, we attempted to investigate the association of sexuality with $O G I$ allele diversities/dosages in a wide range of $D$. kaki cultivars. The results indicated that $O G I$ is indispensable for the monoecious phenotype producing male flowers, which suggested a conserved role for $O G I$ as a key to 20 expressing maleness in D. kaki, as in dioecious diploid Diospyros. However, the existence of $O G I$ alleles did not always lead to production of male flowers in $D$. kaki. The dosage or composition of $O G I$ alleles had no substantial effect on the sexuality of the cultivars tested. We discuss the potential use of the obtained information on $O G I$ allele diversities/dosages for breeding of D. kaki cultivars.
\end{abstract}

\title{
25 Highlights
}

- $O G I$ is basically indispensable for producing male flowers in Oriental persimmon.

- Allelic status of $O G I$ has no substantial effect on the sexuality.

- $O G I$ will be applicable for marker assisted selection for sexuality in Oriental persimmon.

30 Keywords: dioecy, Diospyros, marker-assisted selection, monoecy, OGI, sex chromosome 


\section{Introduction}

Separate sexes in plants, as represented by dioecy (the presence of separated male and female individuals), monoecy (formation of separate male and female flowers in an individual) or their variants,

35 is one of the main strategies to maintain genetic diversity in a species (Charlesworth, 2013). More than $75 \%$ of flowering plant species are supposed to show hermaphrodite systems, while a minority of plant species have evolved separate sexes (Ming et al., 2011; Yampolsky and Yampolsky, 1922). In crops with separate sexes, artificial control of sexuality is an important issue for both production and breeding (Rowlands, 1964). In general, fruit production depends on the amount of female flowers/trees, while male

40 flowers/trees are indispensable for fertilization and seed formation. Thus, the balances of male and female are critical for production efficiency. Cross breeding for new superior cultivars depends on potential fruit characters of both parents. In cross-breeding of dioecious fruit trees, breeders usually have to select a male parent whose genetic effects on fruit characteristics are unknown.

In contrast to the sex determination system in animals, the genetic factors controlling plant sexualities are less known (Bachtrog, 2013). Genes involved in the expression of monoecy or its associated sexualities have been isolated in maize (Zea mays) and Cucumis species (Chuck et al., 2007; Martin et al., 2009). Conversely, the genetic determinants for dioecy, which are defined as located on the "sex chromosome", have remained unidentified for a long time, although plant sex chromosomes have been studied for over a century (Charlesworth, 2015; Ming et al., 2011). This is partially because of the 50 heteromorphism of old plant sex chromosomes, which is generally associated with a long suppressed recombination region. In the $\mathrm{XY}$ heterogametic male system, this region is called the "male specific region of the Y-chromosome (MSY)" (Charlesworth, 2013; Ming et al., 2011). Recently, progress was made on the homomorphic sex chromosomes in some dioecious plant species, such as Caucasian persimmon (D. lotus), kiwifruit (Actinidia spp.) and grape (Vitis spp.) (Akagi et al., 2014a, b; Picq et al., 2014; Zhang et al., 2015). In D. lotus, a genome-wide cataloging of male-specific subsequences with high coverage revealed the sex determinant, $O G I$. $O G I$ is a Y-chromosome-encoded gene that produces small-RNAs targeting an autosomal homologous gene, Male Growth Inhibitor (MeGI), acting as a repressor of male organ development (Akagi et al., 2014a). OGI is conserved specifically in male individuals in a wide variety of Diospyros species, which corresponds well with the notion that the establishment of this dioecious sex determination system predates the divergence of the Diospyros genus, 
and the species nested in this genus share the same sex determination mechanisms (Akagi et al., 2014a). However, hexaploid persimmon (D. kaki) shows flexible sexuality generally not observed in other diploid Diospyros species; it is mainly constituted of female and monoecious trees (Yonemori et al., 1993), with male trees occurring rarely (Xu et al., 2008; Yakushiji et al., 1995). Importantly, preliminary data suggested that the monoecious trait was associated with the existence of the Y-chromosome in $D$. kaki, although the details remain to be elucidated (Akagi et al., 2014a, b; Kajita et al., 2015).

Dioecious plant species that have experienced polyploidization often show a change in sexuality to "intersexuality", such as a hermaphroditic system. Although the molecular mechanisms behind the change in sexuality with polyploidization are still unknown, the allele balances of X-chromosomes and autosomes are supposed to be an important factor for the expression of intersexuality in some XY-type dioecious species, such as Rumex and Humulus (Ming et al., 2007, 2011; Ono, 1935; Parker and Clark, 1991). Conversely, papaya (Carica papaya), Silene latifolia, and kiwifruit (Actinidia spp.) show no distinct changes in sex expression with polyploidization (Ming et al., 2011). The mechanisms underlying these differences in sexuality have not been elucidated, presumably because the sex determinants remain

to be identified. In hexaploid persimmon, six homologous chromosomes are suggested to have autohexaploid or autoallohexaploid inheritance, at least in the locus regulating the astringency of the fruit (Akagi et al., 2009, 2012). However, the relationship between the polyploid nature or allele balances of the sex chromosomes in D. kaki and its flexible sexuality remains to be clarified. Here, we aimed to examine the association of sexuality with the allele diversities/dosages of the Y-encoded $O G I$ gene in various $D$. kaki cultivars.

\section{Materials and Methods}

\subsection{Definition of sexuality in D. kaki cultivars}

One-hundred and seventy-two D. kaki cultivars, which are maintained in the orchard of Kyoto 85 University, Kyoto, Japan, were assessed for their sex expression patterns in 2007-2016. Most of the 172 cultivars were hexaploid $(2 \mathrm{n}=90, \mathrm{x}=15)$ but two were nonaploid (Table 1). Here, we define "monoecious (FM)" and "female (F)" as cultivars bearing both male and female flowers, and bearing only female flowers, respectively. FM-type cultivars occasionally bear hermaphrodite-like flowers with a developed ovary and fully functional stamen. The sexualities of the 172 cultivars were also annotated 
according to a previous report (Fruit Tree Experiment Station of Hiroshima Prefecture, 1979) and the NIAS Genebank database (https://www.gene.affrc.go.jp/databases-plant_search_char.php) (Table 1). Note that there were some differences in sexuality among our observations, the report and the database, as shown in Table 1 . In this study, cultivars were annotated as monoecious when the existence of male flowers was confirmed in at least our observations or the latest database of the NIAS Genebank.

\subsection{PCR detection of $\mathrm{OGI}$ in $\mathrm{D}$. kaki cultivars and $F_{1}$ progeny}

Genomic DNAs were extracted from all the cultivars described above using the CTAB method (Doyle and Doyle, 1987), and then OGI was amplified by PCR using two primer pairs, OGI-candF1 and OGI-spR (Akagi et al., 2014a), and OGI-F1 (5'-AATGCAAGCGGATACACACA-3', $T_{\mathrm{m}}:$ 60.1) and 100 OGI-R2 (5'-CCGTCAATTTTGAGGGAGAG-3', $\left.T_{\mathrm{m}}: 59.7\right)$, with a program of $95^{\circ} \mathrm{C}$ for 3 min followed by 32 cycles of $95^{\circ} \mathrm{C}$ for $20 \mathrm{~s}, 56^{\circ} \mathrm{C}$ for $15 \mathrm{~s}$, and $72^{\circ} \mathrm{C}$ for $1 \mathrm{~min}$. The genomic fragment of $\mathrm{D}$. kaki ANTHOCYANIDIN REDUCTASE (DkANR; accession no. AB195284) was amplified as a reference to confirm the presence of genomic DNA, as described by Akagi et al. (2010). Fifty-nine of the 172 cultivars gave $O G I$ amplification and were subjected to quantitative genotyping and sequencing analysis of $O G I$, as described below.

To estimate the manner of inheritance and the dosage of $O G I$ alleles, PCR analyses, using the OGI-candF1 and OGI-spR primers and the PCR program described above, were conducted to detect $O G I$ in D. kaki $\mathrm{F}_{1}$ populations derived from four crosses; the 310-line ('Luo-tian-tian-shi' $\times$ 'Taishu'), the RI-line ('Luo-tian-tian-shi' × 'Iwasedo'), the RO-line ('Luo-tian-tian-shi' × 'Okugosho'), and the RY-line 110 ('Luo-tian-tian-shi' $\times$ 'Yotsumizo'), as previously reported (Ikegami et al., 2005, 2006). The expected ratio of $O G I$-positive individuals under the autohexasomic and autoallohexasomic inheritance models in the $F_{1}$ progeny was calculated according to Akagi et al. (2010), as suggested for the ASTRINGENCY-linked loci. The fit of the $O G I$-positive ratio in each $\mathrm{F}_{1}$ progeny to the expected ratio was assessed by the Chi-square test.

\subsection{Quantitative genotyping of OGI}

The 59 cultivars showing putative $O G I$ amplification were subjected to quantitative genotyping of $O G I$ by qPCR using a LightCycler 480 (Roche Diagnostics, Mannheim, Germany), according to a 
previous report on the quantitative genotyping of ASTRINGENCY-linked loci (Akagi et al., 2010) with small modifications. This corresponded to detection of the dosage of the Y-chromosomes. The primer set OGI-F2 (5'-AACCCCATCGCATTTGATAA-3', $\left.T_{\mathrm{m}}: 60.2\right)$ and OGI-R2 was used to detect the $O G I$ genomic region. The primer sets DkANR-RTF1 and DkANR-RTR1, and Consv-5F and Consv-5R were used to detect the reference regions $D k A N R$ and L5R, which encode an anthocyanidin reductase and putative ORF with no annotation, respectively (Akagi et al. 2010). Various Diospyros species show high sequence similarity for these reference regions (T. Akagi unpublished), and six alleles in each site are conserved among the D. kaki cultivars as reported by Akagi et al. (2010, 2012). qPCR analyses were conducted under the following conditions: $95^{\circ} \mathrm{C}$ for $5 \mathrm{~min}$ followed by 40 cycles of $95^{\circ} \mathrm{C}$ for $15 \mathrm{~s}, 60^{\circ} \mathrm{C}$ for $15 \mathrm{~s}$, and $72^{\circ} \mathrm{C}$ for $30 \mathrm{~s}$, using THUNDERBIRD SYBR qPCR Mix (TOYOBO, Osaka, Japan). Three technical replicates were performed for each cultivar.

\subsection{Allele sequencing of $\mathrm{OGI}$ in $\mathrm{D}$. kaki cultivars}

The PCR products amplified from the 59 cultivars in the PCR detection of OGI, using two primer pairs described above, OGI-candF1 and OGI-spR, and OGI-F1 and OGI-R2, with the PCR conditions described above, were used for sequencing of almost the full length of $O G I$. After alkaline phosphatase and exonuclease treatment using ExoSAP-IT (Affymetrix, Tokyo, Japan), the treated PCR products were directly subjected to sequencing analysis. Furthermore, the amplified $O G I$ sequences from three of the 59 cultivars ('Nagara', 'Zenjimaru', 'Hanagosho') were purified using a FastGene ${ }^{\mathrm{TM}}$ Gel/PCR Extraction Kit (Nippon Genetics, Tokyo, Japan) and then cloned into pGEM-T easy vectors to be sequenced. Unreliable residues of the sequences were cut off using BioEdit. For direct sequencing analysis, the SNPs in the nucleotide sequences were visually characterized from the overlapped waves. For TA-cloning sequence analysis, about 10 clones were sequenced and the sequences obtained were aligned by using MAFFT v. 7 (Katoh and Standley, 2013) to detect informative SNPs among the alleles. Haplotypes among the SNPs observed across the 59 cultivars were examined, and the association between the $O G I$ allele compositions and individual sexualities was assessed by Fisher's exact test.

\section{Results and Discussion}

3.1. Association in OGI gene and the sexuality in D. kaki cultivars 
PCR amplification for $O G I$ was positive in 59 of the 172 cultivars assessed in this study (Fig. 1,

Table 1). The PCR results using two different primer pairs were consistent (data not shown). All 35 monoecious cultivars (or cultivars bearing both male and female flowers) had $O G I$ alleles in their genomes (Fig. 1). Among 137 female cultivars tested, 24 cultivars showed OGI PCR amplification, while other 113 cultivars had no $O G I$ alleles. Thus, these results suggested that the presence of $O G I$ allele is essential for expressing maleness in polyploid D. kaki, as in other dioecious Diospyros species (Akagi et al., 2014a). The results also suggested that the presence of an $O G I$ allele is not always genetically sufficient for expression of maleness. Considering that monoecious D. kaki cultivars that are genetically male trees carrying $O G I$ alleles have the ability to bear female flowers in addition to male flowers, it is possible that expression of $O G I$ is mostly silenced or under the control of environmental factors in $D$. kaki.

Compared with diploid Diospyros species, polyploid persimmons potentially have much more complicated allele compositions for their sex chromosomes (Table 2). If we consider the heterozygotic composition of hexaploid persimmons, the sex chromosome composition can be from simplex (XXXXXY, single dose for Y) to quintuplex (XYYYYY, pentavalent dose for Y), as with other loci involved in fruit astringency (Akagi et al., 2010). Quantitative genotyping of $O G I$ locus by qPCR analysis showed $O G I$ allele dosage variations from a single to triple doses in the 59 cultivars with $O G I$ (Table 3), although we could not rule out the possibility that $O G I$ was duplicated on the same Y chromosome or in the autosomal region. Our preliminary qPCR genotyping results obtained using a marker linked to OGI, DISxAF4S (Akagi et al., 2014b), for some duplex cultivars (data not shown) were consistent with the OGI qPCR genotyping results, indicating that our analyses could precisely detect allele dosage of OGI (or Y-chromosomes). Quantitative genotyping indicated a weak association between the $O G I$ allele dosage and the ability to produce male flowers (Table $3, P=0.21$ ). The cultivar showing triplex $O G I$, 'Tohachi', is a representative male-rich cultivar, at least in the experimental orchard of Kyoto University. Some of the cultivars showing duplex $O G I$, such as 'Iwasedo', 'Hanagosho', and 'Taishu', are also representative monoecious cultivars. However, even cultivars with duplex $O G I$, such as 'Kunitomi', bear only female flowers. Thus, we concluded that the dosage of $O G I$ is not a crucial determinant of monoecy. The results 175 from the quantitative genotyping were supported by the OGI allele segregation ratio in the four segregating populations. In these populations, the ratio of $O G I$ positive in the crosses of 'Luo-tian-tian-shi' 
x 'Taishu' or 'Iwasedo' (see Table 3 for their estimated $O G I$ dosages by qPCR) gave better fit in nulliplex $\mathrm{x}$ duplex, than in nulliplex $\mathrm{x}$ simplex (Table 4). On the other hand, 'Luo-tian-tian-shi' $\mathrm{x}$ 'Okugosho' or 'Yotsumizo' showed better fit in nulliplex x simplex. The segregation ratio of them mostly fitted to the expected ratio under autohexasomic or autoallohexasomic inheritance modes, as is the case with the ASTRINGENCY locus (Akagi et al., 2012) (Table 4).

Some monoecious persimmon cultivars bear morphologically hermaphrodite flowers in addition to male flowers, although the genetic and environmental factors controlling hermaphrodite flower formation are unknown. Some dioecious plant species, such as Rumex or Humulus, occasionally show intersexuality (hermaphrodite and male/female flowers) upon polyploidization, for which the dosage balance between the X-chromosomes and autosomes is critical (Grant et al., 1994; Ming et al., 2007; Ono, 1935; Parker and Clark, 1991). Although the frequency of hermaphroditic flowers in monoecious persimmon cultivars remains to be characterized fully, the cultivars used in this study showed no clear association between hermaphrodite-like (intersexual) flower formation and the balance of $\mathrm{X}$ - or 190 Y-chromosomes to autosomes (Table 3). This situation fits the so-called "active-Y" system found in kiwifruit or Silene spp., in which sexuality is determined by the presence of Y-chromosome but not affected by the ratio in sex chromosomes and autosomes (Ming et al., 2011; Seal et al., 2012). The sex determination system in persimmons can be also described as "active-Y" because the dosage of $O G I$ seems to be unimportant for expression of maleness and intersexuality.

\subsection{Allele sequencing of $\mathrm{OGI}$ in $\mathrm{D}$. kaki cultivars}

Although the sizes of PCR amplicons of $O G I$ were identical, two kinds of SNPs were found in the directly sequenced PCR products of the $O G I$ alleles from 59 cultivars. Alignments of about 10 each sequences obtained from separately cloned $O G I$ alleles in the 12 cultivars gave the consistent results to

the results obtained from direct sequencing analysis and the phases (or haplotypes) of the clones were likely conserved among the cultivars (Fig. 2A and Table 3). Furthermore, the allele types of these two SNPs were consistent with the estimated $O G I$ allele dosage that was estimated by qPCR. In the cultivars with duplex $O G I$, for instance, the two SNPs haplotypes were expected to exist in 1:1, except 'Taishu' which seemed to have two identical OGI sequences (accession LC120366, Table 3). On the other hand, in the cultivars with simplex $O G I$, only one of the two SNPs haplotypes were detected. No association or 
co-segregation was detected between the $O G I$ allele composition and individual sexuality in the tested persimmon cultivars (Fig. 2B, Table 3). One of the two SNPs was located inside the inverted repeat region which may produce small-RNAs by hybridizing with the forwarded repeat region (Fig. 2A). The other one was in an intron which is not critical for the production of small-RNAs in $O G I$. Sequence variations in the target of the $O G I$ gene, $M e G I$, might be associated with the ability to bear male flowers, because the $O G I$ smRNAs act only when transitive RNAi is stimulated for the MeGI mRNA (Akagi et al., 2014a). Comprehensive sequencing of the putative polysomic alleles of $M e G I$ and investigation of the sequence affinity to $O G I$ alleles may further clarify the molecular basis of the complicated and unstable sexuality in D. kaki.

\section{Conclusion}

This study suggested that the presence of $O G I$ alleles is indispensable for male flower formation in $D$. kaki, but not sufficient to express a monoecious phenotype. Future physiological analysis, especially focusing on the smRNA regulatory network involving $O G I$ and $M e G I$, would give new insights into this unique sex expression mechanism in $D$. kaki. Although the allele dosage might have a small effect on male flower formation ability, variations in the $O G I$ sequence seemed to have little effect on sex determination in the cultivars tested in this study. Information on the dosage of $O G I$ would be important to determine parentages in breeding. In a hexasomic inheritance mode, crossing a female parent with nulliplex $O G I$ and a monoecious parent with multiplex $O G I$ would produce at least $80 \%$ offspring with

OGI alleles (Table 2), which could potentially become monoecious trees. The production of male flowers is not desirable for persimmon cultivation (Hayashi et al., 2001) and thus marker-assisted selection of OGI-null female offspring could be a good strategy for future persimmon breeding. Furthermore, selection of male parents with less $O G I$ alleles would reduce the ratio of potentially monoecious offspring, resulting in efficient breeding of new female cultivars. A drawback of MAS using the $O G I$ sequence is 230 that female individuals are present among the individuals with $O G I$ gene, which would be judged as individuals potentially producing male flowers and removed during selection.

\section{Acknowledgements}

This work was supported by PRESTO, the Japan Science and Technology Agency (to TA), and a 
Grant-in-Aid for Young Scientists (A) (no. 26712005 to TA) and for Challenging Exploratory Research (no. $15 \mathrm{~K} 14654$ to TA and no. 26660025 to RT) from JSPS.

\section{Literature Cited}

Akagi, T., Henry, I.M., Tao, R. and Comai, L., 2014a. A Y-chromosome-encoded small RNA acts as a sex determinant in persimmons. Science 346, 646-650.

Akagi, T., Kajita, K., Kibe, T., Morimura, H., Tsujimoto, T., Nishiyama, S., Kawai, T., Yamane, H., Tao, R., 2014b. Development of molecular markers associated with sexuality in Diospyros lotus L. and their application in D. kaki Thunb. J. Jpn. Soc. Hort. Sci. 83, 214-221.

Akagi, T., Kanzaki, S., Gao, M., Tao, R., Parfitt, D.E., Yonemori, K., 2009. Quantitative real-time PCR to determine allele number for the astringency locus by analysis of a linked marker in Diospyros kaki Thunb. Tree Genet. Gen. 5, 483-492.

Akagi, T., Takeda, Y., Ikegami, A., Kono, A., Yamada, M., Kanzaki, S., Yonemori, K., 2010. Quantitative genotyping for the astringency locus in hexaploid persimmon cultivars using quantitative real-time PCR. J. Amer. Soc. Hort. Sci. 135, 59-66.

Akagi, T., Tao, R., Tsujimoto, T., Kono, A., Yonemori, K., 2012. Fine genotyping of a highly polymorphic ASTRINGENCY-linked locus reveals variable hexasomic inheritance in persimmon (Diospyros kaki Thunb.) cultivars. Tree Genet. Gen. 8, 195-204.

Bachtrog, D., 2013. Y-chromosome evolution: emerging insights into processes of Y-chromosome degeneration. Nat. Rev. Genet. 14, 113-124.

255 Charlesworth, D., 2013. Plant sex chromosome evolution. J. Exp. Bot. 64, 405-420.

Charlesworth, D., 2015. Plant contributions to our understanding of sex chromosome evolution. New Phytol. 208, 52-65.

Chuck, G., Meeley, R., Irish, E., Sakai, H., Hake, S., 2007. The maize tasselseed4 microRNA controls sex determination and meristem cell fate by targeting Tasselseed6/indeterminate spikelet1. Nat. Genet. 39, 1517-1521.

Doyle, J.I., Doyle, J.L., 1987. A rapid DNA isolation procedure for small quantities or fresh leaf tissue of woody plants. Phytochem. Bull. 19, 11-15.

Fruit Tree Experiment Station of Hiroshima Prefecture, 1979. Showa 53-nendo 
Shubyo-tokusei-bunrui-chosa-hokokusho (Kaki). Fruit Tree Experiment Station of Hiroshima Prefecture, Akitsu, Hiroshima.

Grant, S., Houben, A., Vyskot, B., Siroky, J., Pan, W-H., Macas, J., Saedler, H., 1994. Genetics of sex determination in flowering plants. Dev. Genet. 15, 214-230.

Hayashi, K, Chijiwa H., Ushijima, K., 2001. Characteristics of sex expression and flower bud formation in Japanese persimmons 'Taishuu'. Bull. Fukuoka Agric. Res. Cent. 20, 58-62.

Ikegami, A., Eguchi, S., Yonemori, K., Yamada, M., Sato, A., Mitani, N., Kitajima, A., 2006. Segregations of astringent progenies in the F1 populations derived from crosses between a Chinese pollination-constant nonastringent (PCNA) 'Luo tian tian shi', and Japanese PCNA and pollination-constant astringent (PCA) cultivars of Japanese origin. HortScience 41, 561-563.

Ikegami, A., Yonemori, K., Kitajima, A., Sato, A., Yamada, M., 2005. Expression of genes involved in proanthocyanidin biosynthesis during fruit development in a Chinese pollination-constant, nonastringent (PCNA) persimmon 'Luo tian tian shi'. J. Amer. Soc. Hort. Sci. 130, 830-835.

Kajita, K., Akagi, T., Yamane, H., Tao, R., Yonemori, K. 2015. The relationship between a maleness-associated region in Diospyros lotus L. and maleness of persimmon (D. kaki Thunb.) cultivars. Hort. Res. (Japan) 14, 121-126.

Katoh, K., Standley, D. M., 2013. MAFFT Multiple Sequence Alignment Software Version 7: improvements in performance and usability. Mol. Biol. Evol. 30, 772-780.

Martin, A., Troadec, C., Boualem, A., Rajab, M., Fernandez, R., Morin, H., Pitrat, M., Dogimont, C., Bendahmane, A., 2009. A transposon-induced epigenetic change leads to sex determination in melon. Nature 461, 1135-1138.

Ming, R., Bendahmane, A., Renner, S.S., 2011. Sex chromosomes in land plants. Annu. Rev. Plant Biol. $62,485-514$.

Ming, R., Wang, J., Moore, P.H., Paterson, A.H., 2007. Sex chromosomes in flowering plants. Amer. J. Bot. 94, 141-150.

Ono, T., 1935. Chromosomen und sexualität von Rumex acetosa. Sci. Rep. Tohoku Imp. Univ. 10,

$$
41-210 .
$$

Parker, J.S., Clark, M.S., 1991. Dosage sex-chromosome systems in plants. Plant Sci. 80, 79-92.

Picq, S., Santoni, S., Lacombe, T., Latreille, M., Weber, A., Ardisson, M., Ivorra, S., Maghradze, D., 
Arroyo-Garcia, R., Chatelet, P., This, P., Terral, J.F., Bacilieri, R., 2014. A small XY chromosomal region explains sex determination in wild dioecious $V$. vinifera and the reversal to hermaphroditism in domesticated grapevines. BMC Plant Biol. 14, 1.

Rowlands, D.G., 1964. Self-incompatibility in sexually propagated cultivated plants. Euphytica 13, $157-162$.

Seal., A. G., Ferguson, A. R., de Silva, H. N., Zhang, J-L., 2012. The effect of $2 n$ gametes on sex ratios in Actinidia. Sex Plant Reprod. 25, 197-203.

300 Xu, L.Q., Zhang, Q.L., Luo, Z.R., 2008. Occurrence and cytological mechanism of 2n pollen formation in Chinese Diospyros spp. (Ebenaceae) staminate germplasm. J. Hort. Sci. Biotech. 83, 668-672.

Yakushiji, H., Yamada, M., Yonemori, K., Sato, A., Kimura, N., 1995. Staminate flower production on shoots of 'Fuyu' and 'Jiro' persimmon (Diospyros kaki Thunb.). J. Jpn. Soc. Hort. Sci. 64, 41-46.

Yampolsky, C., Yampolsky, H., 1922. Distribution of sex forms in the phanerogamic flora. Bibliotheca Genetica 3, 1-62.

Yonemori, K., Sugiura, A., Tanaka, K., Kameda, K., 1993. Floral ontogeny and sex determination in monoecious-type persimmons. J. Amer. Soc. Hort. Sci. 118, 293-297.

Zhang, Q., Liu, C., Liu, Y., VanBuren, R., Yao, X., Zhong, C., Huang, H., 2015. High-density interspecific genetic maps of kiwifruit and the identification of sex-specific markers. DNA Res. 22, 367-375. 
Figure legends

Figure 1. (A) PCR detection of $O G I$ in 35 monoecious cultivars (FM; 1-35) and 44 female cultivars (F; 36-79). Each number corresponds to the cultivar shown in Table 1. Arrows (ca 970-bp) indicate the expected size of amplification products. m, DNA size marker; M, D. lotus 'Kunsenshi' male tree (positive control); F, 'Kunsenshi' female tree (negative control); N, distilled water (negative control). $D$. kaki ANTHOCYANIDIN REDUCTASE (DkANR) was amplified as a reference to confirm the presence of genomic DNA. (B) Number and ratio of cultivars that produced OGI amplification among the 172 cultivars used in this study. The results of monoecious (FM) and female (F) cultivars are shown separately. OGI+ and OGI- represent $O G I$-positive and -negative, respectively.

Figure 2. (A) Positions of the two SNPs (SNP-1 and SNP-2) detected by sequencing analyses of $O G I$. The positions of SNP-1 (C or T) and SNP-2 (T or C), which were observed across the 59 cultivars carrying $O G I$, are shown with grey triangles on the schematic structure of $O G I$. Boxes and lines represent the putative exons and introns of the $O G I$ gene, respectively. The phases of these two SNPs were conserved among the cultivars as shown with dashed line arrows, making two kinds of haplotypes (haplotype-1 and -2) for $O G I$. (B) $O G I$ allele compositions and individual sexuality in the tested persimmon cultivars. $\mathrm{H} 1$ and $\mathrm{H} 2$ indicate cultivars with haplotype-1 and -2 for $O G I$, respectively, and "H1 + H2" represents those with both. FM, monoecious cultivars; F, female cultivars; n.s., not significant for the association of $O G I$ allele compositions and individual sexuality. 
Table 1

Definition of sexuality and detection of $O G I$ in various persimmon cultivars.

\begin{tabular}{|c|c|c|c|c|c|c|}
\hline \multirow{2}{*}{ No. } & \multirow{2}{*}{ Cultivar } & Refe & ence se & uality $^{2}$ & Sexuality in & $O G I^{v}$ \\
\hline & & $\mathrm{KT}^{\mathrm{y}}$ & $\mathrm{HS}^{\mathrm{x}}$ & NIAS $^{\mathrm{w}}$ & this study & \\
\hline 1 & Akazu & FM & $\mathrm{F}$ & - & FM & $\mathrm{p}$ \\
\hline 2 & Amayotsumizo & FM & FM & - & FM & $\mathrm{p}$ \\
\hline 3 & Cal. Fuyu & FM & - & - & FM & $\mathrm{p}$ \\
\hline 4 & Egosho & FM & FM & FM & FM & $\mathrm{p}$ \\
\hline 5 & Emon & FM & FM & $\mathrm{F}$ & FM & $\mathrm{p}$ \\
\hline 6 & Fudegaki & FM & FM & FM & FM & $\mathrm{p}$ \\
\hline 7 & Fujiwaragosho & FM & FM & $\mathrm{F}$ & FM & $\mathrm{p}$ \\
\hline 8 & Hanagosho & FM & FM & FM & FM & $\mathrm{p}$ \\
\hline 9 & Hazegosho & FM & FM & FM & FM & $\mathrm{p}$ \\
\hline 10 & Ibogaki & FM & $\mathrm{F}$ & $\mathrm{F}$ & FM & $\mathrm{p}$ \\
\hline 11 & Issaigaki & FM & - & - & FM & $\mathrm{p}$ \\
\hline 12 & Iwasedo & FM & FM & FM & FM & $\mathrm{p}$ \\
\hline 13 & Kakiyamagaki & FM & FM & FM & FM & $\mathrm{p}$ \\
\hline 14 & Kanshu & FM & - & - & FM & $\mathrm{p}$ \\
\hline 15 & Kikumanju & FM & - & - & FM & $\mathrm{p}$ \\
\hline 16 & Kyara & FM & FM & $\mathrm{F}$ & FM & $\mathrm{p}$ \\
\hline 17 & Meotogaki & FM & FM & FM & FM & $\mathrm{p}$ \\
\hline 18 & Muraya & FM & FM & FM & FM & $\mathrm{p}$ \\
\hline 19 & Mushirodagosho & FM & FM & - & FM & $\mathrm{p}$ \\
\hline 20 & Nishimurawase & FM & FM & FM & FM & $\mathrm{p}$ \\
\hline 21 & Okugosho & FM & FM & FM & FM & $\mathrm{p}$ \\
\hline 22 & Saburouza & FM & FM & $\mathrm{F}$ & FM & $\mathrm{p}$ \\
\hline 23 & Seihakuji & FM & FM & FM & FM & $\mathrm{p}$ \\
\hline 24 & Shiroutodamashi & FM & FM & FM & FM & $\mathrm{p}$ \\
\hline 25 & Shougatsu & FM & FM & FM & FM & $\mathrm{p}$ \\
\hline 26 & Shoujou & FM & FM & FM & FM & $\mathrm{p}$ \\
\hline 27 & Shouzaemon & FM & $\mathrm{F}$ & - & FM & $\mathrm{p}$ \\
\hline 28 & Taishu & FM & - & - & FM & $\mathrm{p}$ \\
\hline 29 & Taiwan-shoushi & FM & FM & FM & FM & $\mathrm{p}$ \\
\hline 30 & Tohachi & FM & FM & - & FM & $\mathrm{p}$ \\
\hline 31 & Toyoka & $\mathrm{F}$ & FM & FM & FM & $\mathrm{p}$ \\
\hline 32 & Yamagaki & FM & - & - & FM & $\mathrm{p}$ \\
\hline 33 & Yamatogosho & FM & $\mathrm{F}$ & $\mathrm{F}$ & FM & $\mathrm{p}$ \\
\hline 34 & Yotsumizo & FM & FM & FM & FM & $\mathrm{p}$ \\
\hline 35 & Zenjimaru & FM & $\mathrm{FM}$ & FM & FM & $\mathrm{p}$ \\
\hline 36 & Atagobou & $\mathrm{F}$ & $\mathrm{F}$ & - & $\mathrm{F}$ & $\mathrm{p}$ \\
\hline 37 & Beniemon & $\mathrm{F}$ & $\mathrm{F}$ & $\mathrm{F}$ & $\mathrm{F}$ & $\mathrm{p}$ \\
\hline 38 & Beniwase & $\mathrm{F}$ & $\mathrm{F}$ & $\mathrm{F}$ & $\mathrm{F}$ & $\mathrm{p}$ \\
\hline 39 & Chagone & F & - & - & $\mathrm{F}$ & $\mathrm{p}$ \\
\hline 40 & Chichibu-issaigaki & $\mathrm{F}$ & - & - & $\mathrm{F}$ & $\mathrm{p}$ \\
\hline 41 & Deshimaru & $\mathrm{F}$ & $\mathrm{F}$ & - & $\mathrm{F}$ & $\mathrm{p}$ \\
\hline 42 & Kawagone & $\mathrm{F}$ & - & - & $\mathrm{F}$ & $\mathrm{p}$ \\
\hline 43 & Koudagosho & F & $\mathrm{F}$ & - & $\mathrm{F}$ & $\mathrm{p}$ \\
\hline 44 & Kunitomi & $\mathrm{F}$ & $\mathrm{F}$ & $\mathrm{F}$ & $\mathrm{F}$ & $\mathrm{p}$ \\
\hline 45 & Mikado & $\mathrm{F}$ & $\mathrm{F}$ & $\mathrm{F}$ & $\mathrm{F}$ & $\mathrm{p}$ \\
\hline 46 & Monpei & F & F & F & $\mathrm{F}$ & $\mathrm{p}$ \\
\hline 47 & Nagara & $\mathrm{F}$ & $\mathrm{F}$ & $\mathrm{F}$ & $\mathrm{F}$ & $\mathrm{p}$ \\
\hline 48 & Nanshi & $\mathrm{F}$ & - & - & $\mathrm{F}$ & $\mathrm{p}$ \\
\hline 49 & Nitari & $\mathrm{F}$ & $\mathrm{F}$ & - & $\mathrm{F}$ & $\mathrm{p}$ \\
\hline 50 & Oogosho & F & F & F & F & $\mathrm{p}$ \\
\hline 51 & Ooniwa & $\mathrm{F}$ & $\mathrm{F}$ & $\mathrm{F}$ & $\mathrm{F}$ & $\mathrm{p}$ \\
\hline 52 & Saisho & $\mathrm{F}$ & $\mathrm{F}$ & $\mathrm{F}$ & $\mathrm{F}$ & $\mathrm{p}$ \\
\hline 53 & Sanenashi & $\mathrm{F}$ & $\mathrm{F}$ & $\mathrm{F}$ & $\mathrm{F}$ & p \\
\hline 54 & Shimokitahagakushi & $\mathrm{F}$ & F & - & $\mathrm{F}$ & $\mathrm{p}$ \\
\hline 55 & Shouro & $\mathrm{F}$ & $\mathrm{F}$ & - & $\mathrm{F}$ & $\mathrm{p}$ \\
\hline 56 & Suruga & $\mathrm{F}$ & $\mathrm{F}$ & $\mathrm{F}$ & $\mathrm{F}$ & $\mathrm{p}$ \\
\hline 57 & Tenjingosho & F & FM & F & F & $\mathrm{p}$ \\
\hline 58 & Yashima & $\mathrm{F}$ & $\mathrm{F}$ & - & $\mathrm{F}$ & $\mathrm{p}$ \\
\hline 59 & Yoshino & $\mathrm{F}$ & $\mathrm{F}$ & - & $\mathrm{F}$ & $\mathrm{p}$ \\
\hline 60 & Aburatsubo & F & F & F & $\mathrm{F}$ & $\mathrm{n}$ \\
\hline 61 & Aizumishirazu & $\mathrm{F}$ & $\mathrm{F}$ & $\mathrm{F}$ & $\mathrm{F}$ & $\mathrm{n}$ \\
\hline 62 & Amahyakume & $\mathrm{F}$ & FM & $\mathrm{F}$ & $\mathrm{F}$ & $\mathrm{n}$ \\
\hline 63 & Anzai & $\mathrm{F}$ & $\mathrm{F}$ & $\mathrm{F}$ & $\mathrm{F}$ & $\mathrm{n}$ \\
\hline 64 & Aoso & $\mathrm{F}$ & $\mathrm{F}$ & - & $\mathrm{F}$ & $\mathrm{n}$ \\
\hline 65 & Atago & F & F & F & $\mathrm{F}$ & $\mathrm{n}$ \\
\hline 66 & Benigosho & $\mathrm{F}$ & $\mathrm{F}$ & $\mathrm{F}$ & $\mathrm{F}$ & $\mathrm{n}$ \\
\hline 67 & Benisakigake & $\mathrm{F}$ & - & - & $\mathrm{F}$ & $\mathrm{n}$ \\
\hline 68 & Butsushigano & F & $\mathrm{F}$ & $\mathrm{F}$ & $\mathrm{F}$ & $\mathrm{n}$ \\
\hline 69 & Chousengaki & F & $\mathrm{F}$ & - & $\mathrm{F}$ & $\mathrm{n}$ \\
\hline 70 & Dennai & $\mathrm{F}$ & $\mathrm{F}$ & $\mathrm{F}$ & $\mathrm{F}$ & $\mathrm{n}$ \\
\hline 71 & Doujouhachiya & F & FM & $\mathrm{F}$ & $\mathrm{F}$ & $\mathrm{n}$ \\
\hline 72 & Eboshi & F & $\mathrm{F}$ & F & $\mathrm{F}$ & $\mathrm{n}$ \\
\hline 73 & Fuyu & $\mathrm{F}$ & $\mathrm{F}$ & $\mathrm{F}$ & $\mathrm{F}$ & $\mathrm{n}$ \\
\hline 74 & Gionbou & $\mathrm{F}$ & $\mathrm{F}$ & $\mathrm{F}$ & $\mathrm{F}$ & $\mathrm{n}$ \\
\hline 75 & Gobangaki & $\mathrm{F}$ & $\mathrm{F}$ & $\mathrm{F}$ & $\mathrm{F}$ & $\mathrm{n}$ \\
\hline 76 & Gofu & $\mathrm{F}$ & $\mathrm{F}$ & $\mathrm{F}$ & $\mathrm{F}$ & $\mathrm{n}$ \\
\hline 77 & Hacchiuri & $\mathrm{F}$ & $\mathrm{F}$ & $\mathrm{F}$ & $\mathrm{F}$ & $\mathrm{n}$ \\
\hline 78 & Hagakushi & $\mathrm{F}$ & $\mathrm{F}$ & $\mathrm{F}$ & $\mathrm{F}$ & $\mathrm{n}$ \\
\hline 79 & Hiragaki & F & $\mathrm{F}$ & $\mathrm{F}$ & $\mathrm{F}$ & $\mathrm{n}$ \\
\hline 80 & Hiratanenashi $^{\mathrm{u}}$ & $\mathrm{F}$ & $\mathrm{F}$ & $\mathrm{F}$ & $\mathrm{F}$ & $\mathrm{n}$ \\
\hline 81 & Hiratanenashi-edagawari & $\mathrm{F}$ & - & - & $\mathrm{F}$ & $\mathrm{n}$ \\
\hline 82 & Hiroshima-shimofuri & $\mathrm{F}$ & $\mathrm{F}$ & - & $\mathrm{F}$ & $\mathrm{n}$ \\
\hline 83 & Houkikoushi & $\mathrm{F}$ & $\mathrm{F}$ & $\mathrm{F}$ & $\mathrm{F}$ & $\mathrm{n}$ \\
\hline 84 & Houkisuishi & $\mathrm{F}$ & $\mathrm{F}$ & - & $\mathrm{F}$ & $\mathrm{n}$ \\
\hline 85 & Ichidagaki & $\mathrm{F}$ & $\mathrm{F}$ & $\mathrm{F}$ & $\mathrm{F}$ & $\mathrm{n}$ \\
\hline 86 & Ichiryou & $\mathrm{F}$ & $\mathrm{F}$ & $\mathrm{F}$ & $\mathrm{F}$ & $\mathrm{n}$ \\
\hline
\end{tabular}

\begin{tabular}{|c|c|c|c|c|c|c|}
\hline \multirow{2}{*}{ No. } & \multirow{2}{*}{ Cultivar } & Refe & ence se & uality $^{2}$ & Sexuality in & $O G I^{v}$ \\
\hline & & $\mathrm{KT}^{\mathrm{y}}$ & $\mathrm{HS}^{\mathrm{x}}$ & NIAS $^{w}$ & this study & \\
\hline 87 & Inayama & $\mathrm{F}$ & $\mathrm{F}$ & $\mathrm{F}$ & $\mathrm{F}$ & $\mathrm{n}$ \\
\hline 88 & Izaemon & $\mathrm{F}$ & $\mathrm{F}$ & $\mathrm{F}$ & $\mathrm{F}$ & $\mathrm{n}$ \\
\hline 89 & Jiro & $\mathrm{F}$ & $\mathrm{F}$ & $\mathrm{F}$ & $\mathrm{F}$ & $\mathrm{n}$ \\
\hline 90 & Jou-hon-shi & $\mathrm{F}$ & $\mathrm{F}$ & $\mathrm{F}$ & $\mathrm{F}$ & $\mathrm{n}$ \\
\hline 91 & Jouren & $\mathrm{F}$ & $\mathrm{F}$ & $\mathrm{F}$ & $\mathrm{F}$ & $\mathrm{n}$ \\
\hline 92 & Kaibuchi & F & $\mathrm{F}$ & $\mathrm{F}$ & $\mathrm{F}$ & $\mathrm{n}$ \\
\hline 93 & Kanro & $\mathrm{F}$ & $\mathrm{F}$ & - & $\mathrm{F}$ & $\mathrm{n}$ \\
\hline 94 & Karasumi & F & $\mathrm{F}$ & - & $\mathrm{F}$ & $\mathrm{n}$ \\
\hline 95 & Kawabata & $\mathrm{F}$ & $\mathrm{F}$ & $\mathrm{F}$ & $\mathrm{F}$ & $\mathrm{n}$ \\
\hline 96 & Keizanbanshi & $\mathrm{F}$ & $\mathrm{F}$ & $\mathrm{F}$ & $\mathrm{F}$ & $\mathrm{n}$ \\
\hline 97 & Kikuhira & $\mathrm{F}$ & $\mathrm{F}$ & $\mathrm{F}$ & $\mathrm{F}$ & $\mathrm{n}$ \\
\hline 98 & Kiyosu-tanenashi & F & $\mathrm{F}$ & $\mathrm{F}$ & $\mathrm{F}$ & $\mathrm{n}$ \\
\hline 99 & Koedagaki & $\mathrm{F}$ & - & $\mathrm{F}$ & $\mathrm{F}$ & $\mathrm{n}$ \\
\hline 100 & Kojimawase & F & - & - & $\mathrm{F}$ & $\mathrm{n}$ \\
\hline 101 & Komino & $\mathrm{F}$ & $\mathrm{F}$ & - & $\mathrm{F}$ & $\mathrm{n}$ \\
\hline 102 & Koushuhyakume & F & $\mathrm{F}$ & $\mathrm{F}$ & $\mathrm{F}$ & $\mathrm{n}$ \\
\hline 103 & Kouyouwase & $\mathrm{F}$ & - & - & $\mathrm{F}$ & $\mathrm{n}$ \\
\hline 104 & Kuramitsu & $\mathrm{F}$ & $\mathrm{F}$ & $\mathrm{F}$ & $\mathrm{F}$ & $\mathrm{n}$ \\
\hline 105 & Kurogaki & $\mathrm{F}$ & $\mathrm{F}$ & $\mathrm{F}$ & $\mathrm{F}$ & $\mathrm{n}$ \\
\hline 106 & Kurokuma & F & - & $\mathrm{F}$ & $\mathrm{F}$ & $\mathrm{n}$ \\
\hline 107 & Luo-tian-tian-shi & $\mathrm{F}$ & - & - & $\mathrm{F}$ & $\mathrm{n}$ \\
\hline 108 & Maekawajiro & F & $\mathrm{F}$ & $\mathrm{F}$ & $\mathrm{F}$ & $\mathrm{n}$ \\
\hline 109 & Matsumotowasefuyu & $\mathrm{F}$ & $\mathrm{F}$ & $\mathrm{F}$ & $\mathrm{F}$ & $\mathrm{n}$ \\
\hline 110 & Midai & $\mathrm{F}$ & $\mathrm{F}$ & $\mathrm{F}$ & $\mathrm{F}$ & $\mathrm{n}$ \\
\hline 111 & Mie & F & $\mathrm{F}$ & - & $\mathrm{F}$ & $\mathrm{n}$ \\
\hline 112 & Mikatanigosho & $\mathrm{F}$ & $\mathrm{F}$ & $\mathrm{F}$ & $\mathrm{F}$ & $\mathrm{n}$ \\
\hline 113 & Mino & $\mathrm{F}$ & $\mathrm{F}$ & $\mathrm{F}$ & $\mathrm{F}$ & $\mathrm{n}$ \\
\hline 114 & Miyazaki-tanenashi & $\mathrm{F}$ & $\mathrm{F}$ & $\mathrm{F}$ & $\mathrm{F}$ & $\mathrm{n}$ \\
\hline 115 & Mizushima & $\mathrm{F}$ & $\mathrm{F}$ & $\mathrm{F}$ & $\mathrm{F}$ & $\mathrm{n}$ \\
\hline 116 & Nanyousuishi & F & - & - & $\mathrm{F}$ & $\mathrm{n}$ \\
\hline 117 & Niikura & $\mathrm{F}$ & $\mathrm{F}$ & $\mathrm{F}$ & $\mathrm{F}$ & $\mathrm{n}$ \\
\hline 118 & Nijuugaki & F & - & - & $\mathrm{F}$ & $\mathrm{n}$ \\
\hline 119 & Nikorokonashiba & $\mathrm{F}$ & $\mathrm{F}$ & - & $\mathrm{F}$ & $\mathrm{n}$ \\
\hline 120 & Obishi & $\mathrm{F}$ & $\mathrm{F}$ & $\mathrm{F}$ & $\mathrm{F}$ & $\mathrm{n}$ \\
\hline 121 & Okujisha & $\mathrm{F}$ & $\mathrm{F}$ & - & $\mathrm{F}$ & $\mathrm{n}$ \\
\hline 122 & Okumyoutan & $\mathrm{F}$ & $\mathrm{F}$ & $\mathrm{F}$ & $\mathrm{F}$ & $\mathrm{n}$ \\
\hline 123 & Okusaijyo & F & - & - & $\mathrm{F}$ & $\mathrm{n}$ \\
\hline 124 & Onihira & $\mathrm{F}$ & $\mathrm{F}$ & - & $\mathrm{F}$ & $\mathrm{n}$ \\
\hline 125 & Oohachiya & $\mathrm{F}$ & - & - & $\mathrm{F}$ & $\mathrm{n}$ \\
\hline 126 & Ookouzu & F & $\mathrm{F}$ & $\mathrm{F}$ & $\mathrm{F}$ & $\mathrm{n}$ \\
\hline 127 & Oonaga & $\mathrm{F}$ & $\mathrm{F}$ & - & $\mathrm{F}$ & $\mathrm{n}$ \\
\hline 128 & Ootanenashi & F & - & - & $\mathrm{F}$ & $\mathrm{n}$ \\
\hline 129 & Ooyotsumizo & F & $\mathrm{F}$ & - & $\mathrm{F}$ & $\mathrm{n}$ \\
\hline 130 & Oshoro & F & $\mathrm{F}$ & $\mathrm{F}$ & $\mathrm{F}$ & $\mathrm{n}$ \\
\hline 131 & Oumidansu & F & $\mathrm{F}$ & $\mathrm{F}$ & $\mathrm{F}$ & $\mathrm{n}$ \\
\hline 132 & Pansu & $\mathrm{F}$ & $\mathrm{F}$ & $\mathrm{F}$ & $\mathrm{F}$ & $\mathrm{n}$ \\
\hline 133 & Pa-shi & F & $\mathrm{F}$ & $\mathrm{F}$ & $\mathrm{F}$ & $\mathrm{n}$ \\
\hline 134 & Rashoutomoe & F & - & - & $\mathrm{F}$ & $\mathrm{n}$ \\
\hline 135 & Rokuzaemon & $\mathrm{F}$ & $\mathrm{F}$ & - & $\mathrm{F}$ & $\mathrm{n}$ \\
\hline 136 & Saijyo & $\mathrm{F}$ & $\mathrm{F}$ & $\mathrm{F}$ & $\mathrm{F}$ & $\mathrm{n}$ \\
\hline 137 & Sakata & $\mathrm{F}$ & $\mathrm{F}$ & - & $\mathrm{F}$ & $\mathrm{n}$ \\
\hline 138 & Sakushu-mishirazu & $\mathrm{F}$ & $\mathrm{F}$ & $\mathrm{F}$ & $\mathrm{F}$ & $\mathrm{n}$ \\
\hline 139 & Sangokuichi & F & $\mathrm{F}$ & $\mathrm{F}$ & $\mathrm{F}$ & $\mathrm{n}$ \\
\hline 140 & Sanja & $\mathrm{F}$ & $\mathrm{F}$ & $\mathrm{F}$ & $\mathrm{F}$ & $\mathrm{n}$ \\
\hline 141 & Shakokushi & $\mathrm{F}$ & $\mathrm{F}$ & $\mathrm{F}$ & $\mathrm{F}$ & $\mathrm{n}$ \\
\hline 142 & Shimamyoutan & F & $\mathrm{F}$ & - & $\mathrm{F}$ & $\mathrm{n}$ \\
\hline 143 & Shinpei & $\mathrm{F}$ & $\mathrm{F}$ & - & $\mathrm{F}$ & $\mathrm{n}$ \\
\hline 144 & Shinshu & $\mathrm{F}$ & - & - & $\mathrm{F}$ & $\mathrm{n}$ \\
\hline 145 & Soushu & $\mathrm{F}$ & - & - & $\mathrm{F}$ & $\mathrm{n}$ \\
\hline 146 & Spur Hiratanenashi & $\mathrm{F}$ & $\mathrm{F}$ & - & $\mathrm{F}$ & $\mathrm{n}$ \\
\hline 147 & Sugitawase & F & - & $\mathrm{F}$ & $\mathrm{F}$ & $\mathrm{n}$ \\
\hline 148 & Suimyou & $\mathrm{F}$ & - & - & $\mathrm{F}$ & $\mathrm{n}$ \\
\hline 149 & Suishi & F & $\mathrm{F}$ & $\mathrm{F}$ & $\mathrm{F}$ & $\mathrm{n}$ \\
\hline 150 & Sunami & $\mathrm{F}$ & - & - & $\mathrm{F}$ & $\mathrm{n}$ \\
\hline 151 & Taiwan-koushi & F & $\mathrm{F}$ & - & $\mathrm{F}$ & $\mathrm{n}$ \\
\hline 152 & Takase & $\mathrm{F}$ & $\mathrm{F}$ & $\mathrm{F}$ & $\mathrm{F}$ & $\mathrm{n}$ \\
\hline 153 & Takeda & $\mathrm{F}$ & $\mathrm{F}$ & - & $\mathrm{F}$ & $\mathrm{n}$ \\
\hline 154 & Takura & $\mathrm{F}$ & $\mathrm{F}$ & - & $\mathrm{F}$ & $\mathrm{n}$ \\
\hline 155 & Ta-mo-pan & F & $\mathrm{F}$ & $\mathrm{F}$ & $\mathrm{F}$ & $\mathrm{n}$ \\
\hline 156 & Tanenashi-jiro & $\mathrm{F}$ & - & - & $\mathrm{F}$ & $\mathrm{n}$ \\
\hline 157 & Tenpougai & F & - & - & $\mathrm{F}$ & $\mathrm{n}$ \\
\hline 158 & Tenryubou & F & FM & - & $\mathrm{F}$ & $\mathrm{n}$ \\
\hline 159 & Tokudagosho & F & $\mathrm{F}$ & - & $\mathrm{F}$ & $\mathrm{n}$ \\
\hline 160 & Tonewase $^{u}$ & $\mathrm{~F}$ & - & - & $\mathrm{F}$ & $\mathrm{n}$ \\
\hline 161 & Totsutanenashi & $\mathrm{F}$ & - & - & $\mathrm{F}$ & $\mathrm{n}$ \\
\hline 162 & Toushi & $\mathrm{F}$ & $\mathrm{F}$ & - & $\mathrm{F}$ & $\mathrm{n}$ \\
\hline 163 & Wakamiya & $\mathrm{F}$ & $\mathrm{F}$ & $\mathrm{F}$ & $\mathrm{F}$ & $\mathrm{n}$ \\
\hline 164 & Wasamatsuo & F & $\mathrm{F}$ & $\mathrm{F}$ & $\mathrm{F}$ & $\mathrm{n}$ \\
\hline 165 & Wasejisha & F & $\mathrm{F}$ & $\mathrm{F}$ & $\mathrm{F}$ & $\mathrm{n}$ \\
\hline 166 & Watarisawa & $\mathrm{F}$ & $\mathrm{F}$ & - & $\mathrm{F}$ & $\mathrm{n}$ \\
\hline 167 & Yamagata-benigaki & F & $\mathrm{FM}$ & $\mathrm{F}$ & $\mathrm{F}$ & $\mathrm{n}$ \\
\hline 168 & Yamato & $\mathrm{F}$ & $\mathrm{F}$ & $\mathrm{F}$ & $\mathrm{F}$ & $\mathrm{n}$ \\
\hline 169 & Yatsudera & $\mathrm{F}$ & $\mathrm{F}$ & $\mathrm{F}$ & $\mathrm{F}$ & $\mathrm{n}$ \\
\hline 170 & Yokono & $\mathrm{F}$ & $\mathrm{F}$ & $\mathrm{F}$ & $\mathrm{F}$ & $\mathrm{n}$ \\
\hline 171 & Yomizo & F & - & - & $\mathrm{F}$ & $\mathrm{n}$ \\
\hline 172 & Yotsuyasaijyo & $\mathrm{F}$ & $\mathrm{F}$ & $\mathrm{F}$ & $\mathrm{F}$ & $\mathrm{n}$ \\
\hline
\end{tabular}


${ }^{\mathrm{z}} \mathrm{FM}$; monoecious cultivar, F; female cultivar, -; data unknown.

${ }^{\mathrm{y}}$ Experimental Orchard of Kyoto University.

${ }^{\mathrm{x}}$ Fruit Tree Experiment Station of Hiroshima Prefecture, 1979.

${ }^{w}$ Database of the NIAS Genebank (https://www.gene.affrc.go.jp/databases-plant_search_char.php).

$340 \quad \mathrm{p}$; positive, $\mathrm{n}$; negative.

unonaploid cultivar. 
Table 2

Ratio of $O G I$-positive individuals in the $\mathrm{F}_{1}$ progeny of crosses between cultivars with multiplex $O G I$ and 345 without $O G I$.

\begin{tabular}{|c|c|c|c|}
\hline \multirow{2}{*}{$\begin{array}{c}\text { Hybridization } \\
\text { (cultivar with } O G I) \times(\text { cultivar without } O G I)\end{array}$} & \multirow{2}{*}{$O G I$ allele dosage ${ }^{\mathrm{z}}$} & \multicolumn{2}{|c|}{ Expected ratio of $O G I$ positive in $\mathrm{F}_{1}(\%)^{\mathrm{y}}$} \\
\hline & & Autohexaploid & Autoallohexaploid \\
\hline YXXXXX x XXXXXX & Single & 50 & 50 \\
\hline YYXXXX x XXXXXX & Double & 80 & 83.3 (YYXX/XX), 75 (YXXX/YX) \\
\hline YYYXXX x XXXXXX & Triple & 95 & $100(\mathbf{Y Y Y X} / \mathbf{X X}$ or $\mathbf{Y X X X / Y Y}), 91.7(\mathbf{Y Y X X} / \mathbf{Y X})$ \\
\hline YYYYXX x XXXXXX & Quandrivalent & 100 & 100 \\
\hline YYYYYX x XXXXXX & Pentavalent & 100 & 100 \\
\hline YYYYYY X XXXXXX & Hexavalent & 100 & 100 \\
\hline
\end{tabular}

$350 \quad{ }^{\mathrm{z}}$ Corresponding to the dosage of Y-chromosomes.

${ }^{\mathrm{y}}$ The expected ratio of $O G I$-positive individuals in the $\mathrm{F}_{1}$ progeny was calculated according to Akagi et al. (2010), focusing on the inheritance mode and the allele dosage of ASTRINGENCY-linked loci in hexaploid persimmon cultivars. 
Table 3

355 Estimation of $O G I$ allele dosage and constitution of sex chromosomes by qPCR analysis.

\begin{tabular}{|c|c|c|c|c|c|c|c|c|}
\hline \multirow[b]{2}{*}{ No. ${ }^{z}$} & \multirow[b]{2}{*}{ Cultivar } & \multirow[b]{2}{*}{ Sexuality } & \multicolumn{2}{|c|}{ Caluculated $O G I$ allele dosage $(\text { no. } \pm \mathrm{SE})^{\mathrm{y}}$} & \multicolumn{2}{|c|}{ SNP alleletype ${ }^{x}$} & \multicolumn{2}{|c|}{ Estimated constitution of the sex chromosomes ${ }^{\mathrm{w}}$} \\
\hline & & & $\begin{array}{c}D k A N R \\
\text { reference } \\
\end{array}$ & $\begin{array}{c}\mathrm{L} 5 \mathrm{R} \\
\text { reference } \\
\end{array}$ & SNP-1 & SNP-2 & $\begin{array}{c}D k A N R \\
\text { reference }\end{array}$ & $\begin{array}{c}\mathrm{L} 5 \mathrm{R} \\
\text { reference }\end{array}$ \\
\hline 1 & Akazu & FM & $0.95 \pm 0.05$ & $0.86 \pm 0.04$ & $\mathrm{C}$ & $\mathrm{T}$ & $Y_{1} X X X X X$ & $Y_{1} X X X X X$ \\
\hline 3 & Cal.Fuyu & FM & $1.24 \pm 0.02$ & $1.09 \pm 0.02$ & $\mathrm{C}$ & $\mathrm{T}$ & $Y_{1} X X X X X$ & $Y_{1} X X X X X$ \\
\hline 4 & Egosho & FM & $0.93 \pm 0.03$ & $0.79 \pm 0.02$ & $\mathrm{~T}$ & $\mathrm{C}$ & $\mathrm{Y}_{2} \mathrm{XXXXX}$ & $\mathbf{Y}_{2} \mathrm{XXXXX}$ \\
\hline 5 & Emon & FM & $0.92 \pm 0.01$ & $0.86 \pm 0.01$ & $\mathrm{C}$ & $\mathrm{T}$ & $\mathrm{Y}_{1} \mathrm{XXXXX}$ & $\mathrm{Y}_{1} \mathrm{XXXXX}$ \\
\hline 6 & Fudegaki & FM & $1.05 \pm 0.00$ & $0.84 \pm 0.00$ & $\mathrm{~T}$ & $\mathrm{C}$ & $\mathrm{Y}_{2} \mathrm{XXXXX}$ & $\mathrm{Y}_{2} \mathrm{XXXXX}$ \\
\hline 7 & Fujiwaragosho & FM & $1.02 \pm 0.02$ & $0.87 \pm 0.02$ & $\mathrm{C}$ & $\mathrm{T}$ & $\mathrm{Y}_{1} \mathrm{XXXXX}$ & $\mathrm{Y}_{1} \mathrm{XXXXX}$ \\
\hline 9 & Hazegosho & FM & $1.15 \pm 0.03$ & $0.94 \pm 0.03$ & $\mathrm{C}$ & $\mathrm{T}$ & $\mathrm{Y}_{1} \mathrm{XXXXX}$ & $\mathrm{Y}_{1} \mathrm{XXXXX}$ \\
\hline 10 & Ibogaki & FM & $1.11 \pm 0.07$ & $0.94 \pm 0.06$ & $\mathrm{C}$ & $\mathrm{T}$ & $\mathrm{Y}_{1} \mathrm{XXXXX}$ & $\mathrm{Y}_{1} \mathrm{XXXXX}$ \\
\hline 11 & Issaigaki $^{\mathrm{v}}$ & FM & $0.96 \pm 0.01$ & $0.91 \pm 0.01$ & $\mathrm{~T}$ & $\mathrm{C}$ & $\mathrm{Y}_{2} \mathrm{XXXXX}$ & $\mathrm{Y}_{2} \mathrm{XXXXX}$ \\
\hline 13 & Kakiyamagaki $^{\mathrm{v}}$ & FM & $1.10 \pm 0.03$ & $0.91 \pm 0.02$ & $\mathrm{~T}$ & $\mathrm{C}$ & $\mathrm{Y}_{2} \mathrm{XXXXX}$ & $\mathrm{Y}_{2} \mathrm{XXXXX}$ \\
\hline 14 & Kanshu & FM & $1.10 \pm 0.03$ & $0.88 \pm 0.03$ & $\mathrm{C}$ & $\mathrm{T}$ & $\mathrm{Y}_{1} \mathrm{XXXXX}$ & $\mathrm{Y}_{1} \mathrm{XXXXX}$ \\
\hline 15 & Kikumanju & FM & $0.85 \pm 0.04$ & $0.79 \pm 0.03$ & $\mathrm{~T}$ & $\mathrm{C}$ & $Y_{2} X X X X X$ & $Y_{2} X X X X X$ \\
\hline 16 & Kyara & FM & $1.14 \pm 0.10$ & $0.91 \pm 0.08$ & $\mathrm{~T}$ & $\mathrm{C}$ & $\mathrm{Y}_{2} \mathrm{XXXXX}$ & $\mathrm{Y}_{2} \mathrm{XXXXX}$ \\
\hline 18 & Muraya & FM & $1.08 \pm 0.02$ & $0.89 \pm 0.02$ & $\mathrm{~T}$ & $\mathrm{C}$ & $\mathrm{Y}_{2} \mathrm{XXXXX}$ & $\mathrm{Y}_{2} \mathrm{XXXXX}$ \\
\hline 19 & Mushirodagosho & FM & $0.92 \pm 0.00$ & $0.77 \pm 0.00$ & $\mathrm{C}$ & $\mathrm{T}$ & $Y_{1} X X X X X$ & $\mathrm{Y}_{1} \mathrm{XXXXX}$ \\
\hline 20 & Nishimurawase & FM & $0.98 \pm 0.03$ & $0.81 \pm 0.02$ & $\mathrm{C}$ & $\mathrm{T}$ & $\mathrm{Y}_{1} \mathrm{XXXXX}$ & $\mathrm{Y}_{1} \mathrm{XXXXX}$ \\
\hline 21 & Okugosho & FM & $1.12 \pm 0.07$ & $0.94 \pm 0.06$ & $\mathrm{C}$ & $\mathrm{T}$ & $Y_{1} X X X X X$ & $\mathrm{Y}_{1} \mathrm{XXXXX}$ \\
\hline 23 & Seihakuji & FM & $0.92 \pm 0.02$ & $0.85 \pm 0.02$ & $\mathrm{~T}$ & $\mathrm{C}$ & $\mathrm{Y}_{2} \mathrm{XXXXX}$ & $\mathrm{Y}_{2} \mathrm{XXXXX}$ \\
\hline 24 & Shiroutodamashi & FM & $1.15 \pm 0.01$ & $1.07 \pm 0.01$ & $\mathrm{C}$ & $\mathrm{T}$ & $\mathrm{Y}_{1} \mathrm{XXXXX}$ & $\mathrm{Y}_{1} \mathrm{XXXXX}$ \\
\hline 25 & Shougatsu ${ }^{v}$ & FM & $1.03 \pm 0.10$ & $0.91 \pm 0.09$ & $\mathrm{~T}$ & $\mathrm{C}$ & $\mathrm{Y}_{2} \mathrm{XXXXX}$ & $\mathrm{Y}_{2} \mathrm{XXXXX}$ \\
\hline 26 & Shoujou & FM & $1.26 \pm 0.03$ & $1.09 \pm 0.02$ & $\mathrm{~T}$ & $\mathrm{C}$ & $\mathrm{Y}_{2} \mathrm{XXXXX}$ & $\mathrm{Y}_{2} \mathrm{XXXXX}$ \\
\hline 27 & Shouzaemon & FM & $0.66 \pm 0.02$ & $0.61 \pm 0.02$ & $\mathrm{~T}$ & $\mathrm{C}$ & $Y_{2} X X X X X$ & $Y_{2} X X X X X$ \\
\hline 29 & Taiwan-shoushi $^{\mathrm{v}}$ & FM & $1.27 \pm 0.03$ & $1.12 \pm 0.02$ & $\mathrm{~T}$ & $\mathrm{C}$ & $Y_{2} X X X X X$ & $\mathrm{Y}_{2} \mathrm{XXXXX}$ \\
\hline 31 & Toyoka & FM & $0.90 \pm 0.02$ & $0.88 \pm 0.02$ & $\mathrm{~T}$ & $\mathrm{C}$ & $Y_{2} X X X X X$ & $Y_{2} X X X X X$ \\
\hline 32 & Yamagaki & FM & $1.09 \pm 0.06$ & $0.83 \pm 0.04$ & $\mathrm{~T}$ & $\mathrm{C}$ & $\mathrm{Y}_{2} \mathrm{XXXXX}$ & $\mathrm{Y}_{2} \mathrm{XXXXX}$ \\
\hline 34 & Yotsumizo & FM & $1.05 \pm 0.02$ & $0.89 \pm 0.02$ & $\mathrm{C}$ & $\mathrm{T}$ & $\mathrm{Y}_{1} \mathrm{XXXXX}$ & $\mathrm{Y}_{1} \mathrm{XXXXX}$ \\
\hline 35 & Zenjimaru & FM & $1.11 \pm 0.02$ & $0.88 \pm 0.02$ & $\mathrm{C}$ & $\mathrm{T}$ & $\mathrm{Y}_{1} \mathrm{XXXXX}$ & $\mathrm{Y}_{1} \mathrm{XXXXX}$ \\
\hline 38 & Beniwase & $\mathrm{F}$ & $0.97 \pm 0.05$ & $0.68 \pm 0.03$ & $\mathrm{~T}$ & $\mathrm{C}$ & $\mathrm{Y}_{2} \mathrm{XXXXX}$ & $\mathrm{Y}_{2} \mathrm{XXXXX}$ \\
\hline 39 & Chagone & $\mathrm{F}$ & $1.22 \pm 0.01$ & $0.99 \pm 0.01$ & $\mathrm{~T}$ & $\mathrm{C}$ & $\mathrm{Y}_{2} \mathrm{XXXXX}$ & $\mathrm{Y}_{2} \mathrm{XXXXX}$ \\
\hline 40 & Chichibu-issaigaki & $\mathrm{F}$ & $0.77 \pm 0.01$ & $0.75 \pm 0.01$ & $\mathrm{~T}$ & $\mathrm{C}$ & $\mathrm{Y}_{2} \mathrm{XXXXX}$ & $\mathrm{Y}_{2} \mathrm{XXXXX}$ \\
\hline 41 & Deshimaru & $\mathrm{F}$ & $1.10 \pm 0.03$ & $0.92 \pm 0.02$ & $\mathrm{~T}$ & $\mathrm{C}$ & $\mathrm{Y}_{2} \mathrm{XXXXX}$ & $\mathrm{Y}_{2} \mathrm{XXXXX}$ \\
\hline 42 & Kawagone & $\mathrm{F}$ & $1.44 \pm 0.07$ & $1.16 \pm 0.06$ & $\mathrm{~T}$ & $\mathrm{C}$ & $\mathbf{Y}_{2} \mathrm{XXXXX}$ or $\mathbf{Y}_{2} \mathbf{Y}_{2} \mathrm{XXXX}$ & $\mathrm{Y}_{2} \mathrm{XXXXX}$ \\
\hline 43 & Koudagosho & $\mathrm{F}$ & $1.15 \pm 0.02$ & $0.95 \pm 0.01$ & $\mathrm{C}$ & $\mathrm{T}$ & $\mathrm{Y}_{1} \mathrm{XXXXX}$ & $\mathrm{Y}_{1} \mathrm{XXXXX}$ \\
\hline 45 & Mikado & $\mathrm{F}$ & $0.96 \pm 0.03$ & $0.83 \pm 0.02$ & $\mathrm{C}$ & $\mathrm{T}$ & $\mathrm{Y}_{1} \mathrm{XXXXX}$ & $\mathrm{Y}_{1} \mathrm{XXXXX}$ \\
\hline 46 & Monpei & $\mathrm{F}$ & $1.19 \pm 0.01$ & $1.14 \pm 0.01$ & $\mathrm{~T}$ & $\mathrm{C}$ & $\mathrm{Y}_{2} \mathrm{XXXXX}$ & $\mathrm{Y}_{2} \mathrm{XXXXX}$ \\
\hline 47 & Nagara & $\mathrm{F}$ & $1.25 \pm 0.02$ & $1.08 \pm 0.02$ & $\mathrm{C}$ & $\mathrm{T}$ & $\mathrm{Y}_{1} \mathrm{XXXXX}$ & $\mathrm{Y}_{1} \mathrm{XXXXX}$ \\
\hline 48 & Nanshi & $\mathrm{F}$ & $1.01 \pm 0.01$ & $0.88 \pm 0.01$ & $\mathrm{C}$ & $\mathrm{T}$ & $\mathrm{Y}_{1} \mathrm{XXXXX}$ & $\mathrm{Y}_{1} \mathrm{XXXXX}$ \\
\hline 49 & Nitari & $\mathrm{F}$ & $0.86 \pm 0.04$ & $0.66 \pm 0.03$ & $\mathrm{C}$ & $\mathrm{T}$ & $\mathrm{Y}_{1} \mathrm{XXXXX}$ & $\mathrm{Y}_{1} \mathrm{XXXXX}$ \\
\hline 50 & Oogosho & $\mathrm{F}$ & $1.11 \pm 0.02$ & $1.01 \pm 0.02$ & $\mathrm{~T}$ & $\mathrm{C}$ & $\mathrm{Y}_{2} \mathrm{XXXXX}$ & $\mathrm{Y}_{2} \mathrm{XXXXX}$ \\
\hline 51 & Ooniwa & $\mathrm{F}$ & $0.99 \pm 0.01$ & $0.96 \pm 0.01$ & $\mathrm{~T}$ & $\mathrm{C}$ & $\mathrm{Y}_{2} \mathrm{XXXXX}$ & $\mathrm{Y}_{2} \mathrm{XXXXX}$ \\
\hline 52 & Saisho & $\mathrm{F}$ & $0.91 \pm 0.21$ & $0.81 \pm 0.19$ & $\mathrm{C}$ & $\mathrm{T}$ & $\mathrm{Y}_{1} \mathrm{XXXXX}$ & $\mathrm{Y}_{1} \mathrm{XXXXX}$ \\
\hline 53 & Sanenashi & F & $1.23 \pm 0.04$ & $0.97 \pm 0.03$ & $\mathrm{C}$ & $\mathrm{T}$ & $\mathrm{Y}_{1} \mathrm{XXXXX}$ & $\mathrm{Y}_{1} \mathrm{XXXXX}$ \\
\hline 54 & Shimokitahagakushi & F & $0.97 \pm 0.01$ & $0.80 \pm 0.01$ & $\mathrm{C}$ & $\mathrm{T}$ & $\mathrm{Y}_{1} \mathrm{XXXXX}$ & $\mathrm{Y}_{1} \mathrm{XXXXX}$ \\
\hline 55 & Shouro & $\mathrm{F}$ & $1.14 \pm 0.07$ & $0.87 \pm 0.05$ & $\mathrm{~T}$ & $\mathrm{C}$ & $\mathrm{Y}_{2} \mathrm{XXXXX}$ & $\mathrm{Y}_{2} \mathrm{XXXXX}$ \\
\hline 56 & Suruga & $\mathrm{F}$ & $0.89 \pm 0.01$ & $0.75 \pm 0.01$ & $\mathrm{~T}$ & $\mathrm{C}$ & $\mathrm{Y}_{2} \mathrm{XXXXX}$ & $\mathrm{Y}_{2} \mathrm{XXXXX}$ \\
\hline 57 & Tenjingosho & $\mathrm{F}$ & $1.15 \pm 0.03$ & $1.03 \pm 0.03$ & $\mathrm{C}$ & $\mathrm{T}$ & $\mathrm{Y}_{1} \mathrm{XXXXX}$ & $\mathrm{Y}_{1} \mathrm{XXXXX}$ \\
\hline 58 & Yashima & $\mathrm{F}$ & $1.10 \pm 0.02$ & $0.94 \pm 0.01$ & $\mathrm{~T}$ & $\mathrm{C}$ & $\mathrm{Y}_{2} \mathrm{XXXXX}$ & $\mathrm{Y}_{2} \mathrm{XXXXX}$ \\
\hline 59 & Yoshino & F & $1.11 \pm 0.03$ & $0.98 \pm 0.03$ & $\mathrm{C}$ & $\mathrm{T}$ & $\mathrm{Y}_{1} \mathrm{XXXXX}$ & $\mathrm{Y}_{1} \mathrm{XXXXX}$ \\
\hline 8 & Hanagosho & FM & $2.11 \pm 0.03$ & $1.73 \pm 0.02$ & $\mathrm{C}: \mathrm{T}=1: 1$ & $\mathrm{~T}: \mathrm{C}=1: 1$ & $\mathbf{Y}_{1} \mathbf{Y}_{2} \mathrm{XXXX}$ & $\mathbf{Y}_{1} \mathbf{Y}_{2} \mathrm{XXXX}$ \\
\hline 12 & Iwasedo & FM & $2.32 \pm 0.05$ & $2.02 \pm 0.05$ & $\mathrm{C}: \mathrm{T}=1: 1$ & $\mathrm{~T}: \mathrm{C}=1: 1$ & $\mathbf{Y}_{1} \mathbf{Y}_{2} \mathrm{XXXX}$ & $\mathbf{Y}_{1} \mathbf{Y}_{2} \mathrm{XXXX}$ \\
\hline 22 & Saburouza & FM & $2.08 \pm 0.04$ & $1.93 \pm 0.04$ & $\mathrm{C}: \mathrm{T}=1: 1$ & $\mathrm{~T}: \mathrm{C}=1: 1$ & $\mathbf{Y}_{1} \mathbf{Y}_{2} \mathrm{XXXX}$ & $\mathbf{Y}_{1} \mathbf{Y}_{2} \mathrm{XXXX}$ \\
\hline 28 & Taishu $^{v}$ & FM & $2.10 \pm 0.04$ & $1.87 \pm 0.03$ & $\mathrm{~T}$ & C & $\mathbf{Y}_{2} \mathbf{Y}_{2} \mathrm{XXXX}$ & $\mathbf{Y}_{2} \mathbf{Y}_{2} \mathrm{XXXX}$ \\
\hline 34 & Yamatogosho & FM & $1.77 \pm 0.02$ & $1.60 \pm 0.02$ & $\mathrm{C}: \mathrm{T}=1: 1$ & $\mathrm{~T}: \mathrm{C}=1: 1$ & $Y_{1} Y_{2} X X X X$ & $\mathbf{Y}_{1} \mathbf{Y}_{2} \mathrm{XXXX}$ \\
\hline 45 & Kunitomi & $\mathrm{F}$ & $1.79 \pm 0.01$ & $1.52 \pm 0.01$ & $\mathrm{C}: \mathrm{T}=1: 1$ & $\mathrm{~T}: \mathrm{C}=1: 1$ & $\mathbf{Y}_{1} \mathbf{Y}_{2} \mathrm{XXXX}$ & $\mathbf{Y}_{1} \mathbf{Y}_{2} \mathrm{XXXX}$ \\
\hline 31 & Tohachi $^{\mathrm{v}}$ & FM & $3.28 \pm 0.03$ & $2.87 \pm 0.03$ & $\mathrm{C}: \mathrm{T}=1: 2$ & $\mathrm{~T}: \mathrm{C}=1: 2$ & $\mathbf{Y}_{1} \mathbf{Y}_{2} \mathbf{Y}_{2} \mathrm{XXX}$ & $\mathbf{Y}_{1} \mathbf{Y}_{2} \mathbf{Y}_{2} \mathrm{XXX}$ \\
\hline \multicolumn{9}{|c|}{ (negative control) } \\
\hline
\end{tabular}


${ }^{\mathrm{z}}$ Corresponding to the cultivar No. in Table 1 .

${ }^{\mathrm{y}} O G I$ allele dosage was calculated as [(relative DNA dosage of $\left.O G I\right) /($ relative DNA dosage of the reference gene)] $\times 2$, based on the possibility that 'Taishu' has two OGI alleles in its genome (see Table 4). The relative DNA dosage was calculated from 360 each Ct using the standard curves of the genomic DNA of 'Taishu'.

${ }^{x}$ Allelotypes at SNP-1 and SNP-2 are shown in Fig. 2. Approximate ratios of the signal strength derived from each allele in direct sequencing are shown in some cultivars carrying multiple $O G I$ alleles.

${ }^{\mathrm{w}}$ Constitution of the sex chromosomes was estimated from the calculated $O G I$ allele dosage and SNP allelotypes; $\mathrm{Y}_{1}$, C/T and $\mathrm{Y}_{2}, \mathrm{~T} / \mathrm{C}$ at SNP-1/SNP-2, respectively.

$365{ }^{\mathrm{v}}$ Cultivars often giving hermaphrodite-like flowers in Kyoto University Experimental Orchard. 
Table 4

Segregation of $O G I$ in four D. kaki F 1 populations; 'Luo-tian-tian-shi’ × 'Taishu' (310), 'Luo-tian-tian-shi’ × 'Iwasedo' (RI), 'Luo-tian-tian-shi’ × 'Okugosho' (RO) and 'Luo-tian-tian-shi' $\times$ 'Yotsumizo' (RY).

\begin{tabular}{|c|c|c|c|c|c|c|c|c|}
\hline \multirow{3}{*}{$\mathrm{F}_{1}$ population $^{\mathrm{z}}$} & \multirow{2}{*}{\multicolumn{2}{|c|}{ PCR signal of $O G I$}} & \multicolumn{5}{|c|}{ Fitness to the expected ratio of $O G I$ positive $(P \text { value })^{\mathrm{y}}$} & \\
\hline & & & \multicolumn{3}{|c|}{ Autohexaploid } & \multicolumn{3}{|c|}{ Autoallohexaploid } \\
\hline & Positive & Negative & Single $(50 \%)^{\mathrm{x}}$ & Double $(80 \%)$ & Triple $(95 \%)$ & Single $(50 \%)$ & Double $(83.3 \% / 75 \%)$ & Triple $(100 \% / 91.7 \%)$ \\
\hline 310 ('Taishu’) & 18 & 8 & 0.037 & 0.137 & $<0.001$ & 0.037 & $0.041 / 0.414$ & $\mathrm{ND}^{\mathrm{w}} /<0.001$ \\
\hline RI ('Iwasedo’) & 78 & 17 & $<0.001$ & 0.608 & $<0.001$ & $<0.001$ & $0.755 / 0.110$ & $\mathrm{ND} /<0.001$ \\
\hline RO ('Okugosho’) & 39 & 61 & 0.028 & $<0.001$ & $<0.001$ & 0.028 & $<0.001 /<0.001$ & $\mathrm{ND} /<0.001$ \\
\hline RY ('Yotsumizo') & 63 & 51 & 0.261 & $<0.001$ & $<0.001$ & 0.261 & $<0.001 /<0.001$ & $\mathrm{ND} /<0.001$ \\
\hline
\end{tabular}

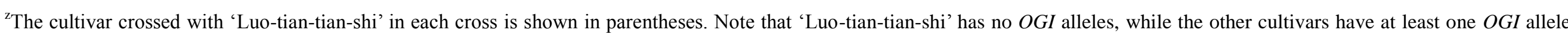

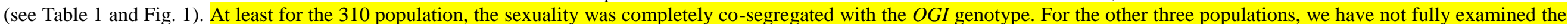
sexuality yet.

${ }^{\mathrm{y}} \mathrm{Chi}$-squared test for expected ratio of $O G I$-positive (: negative) individuals shown in Table 2.

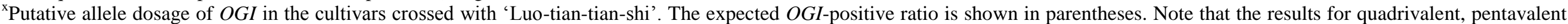
and hexavalent are not shown because $P$ values could not be determined by the Chi-square test.

${ }^{\mathrm{w}}$ Not determined. 
Figure 1

(A)

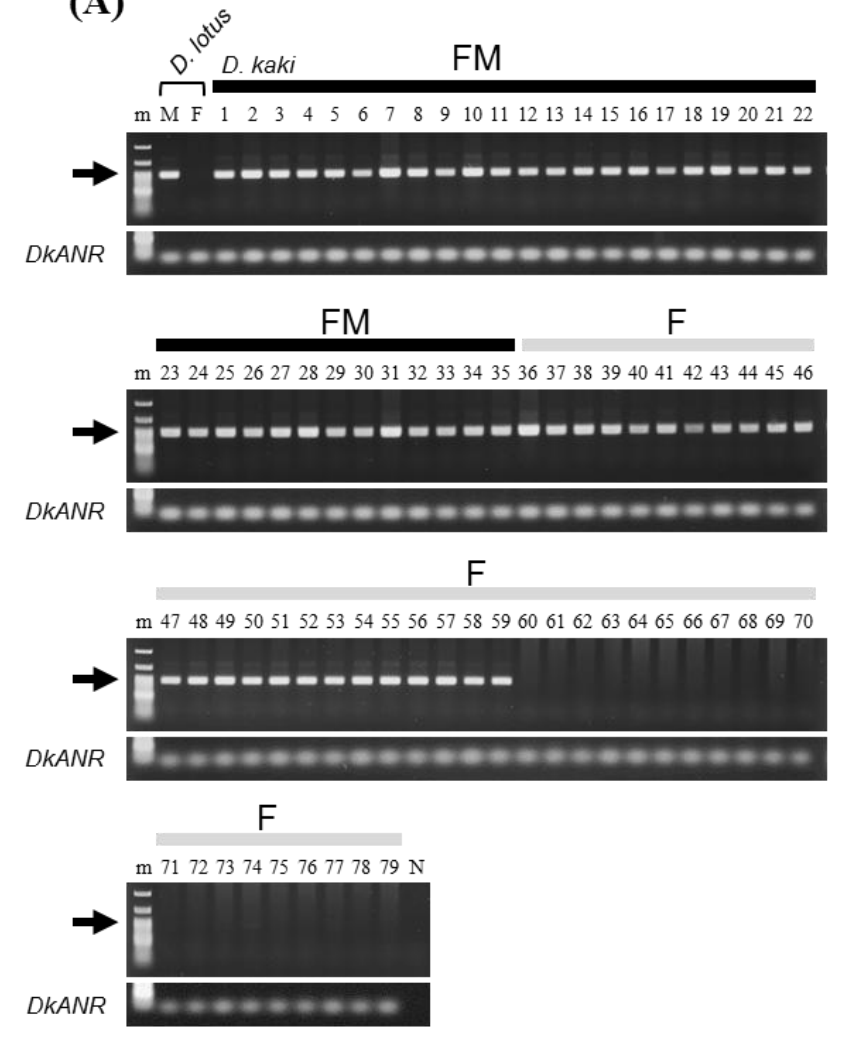

(B)

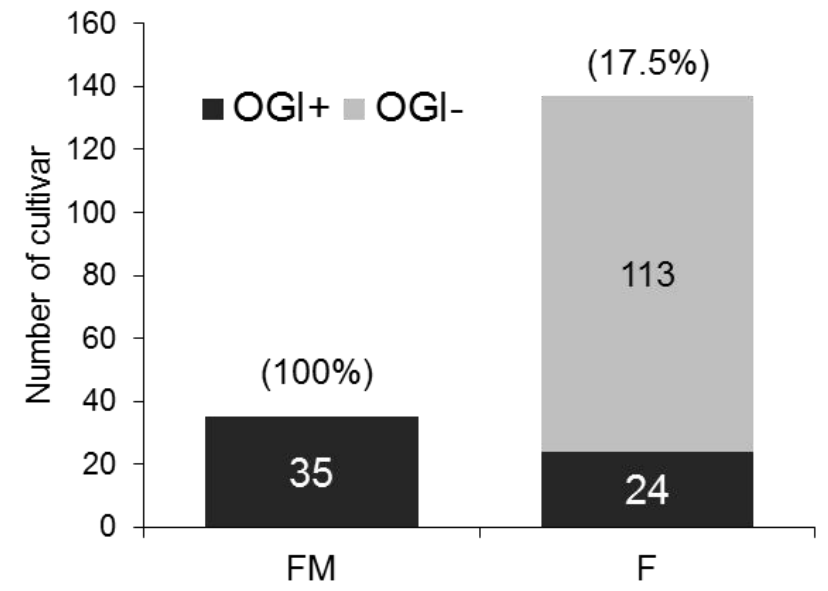


Figure 2

(A)

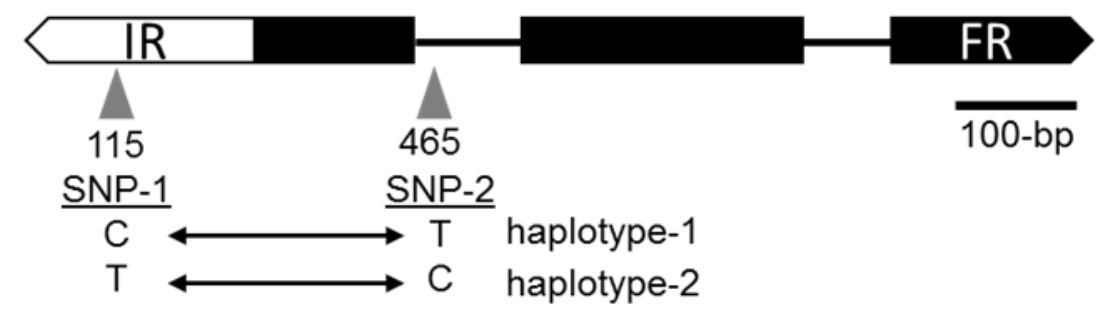

(B)

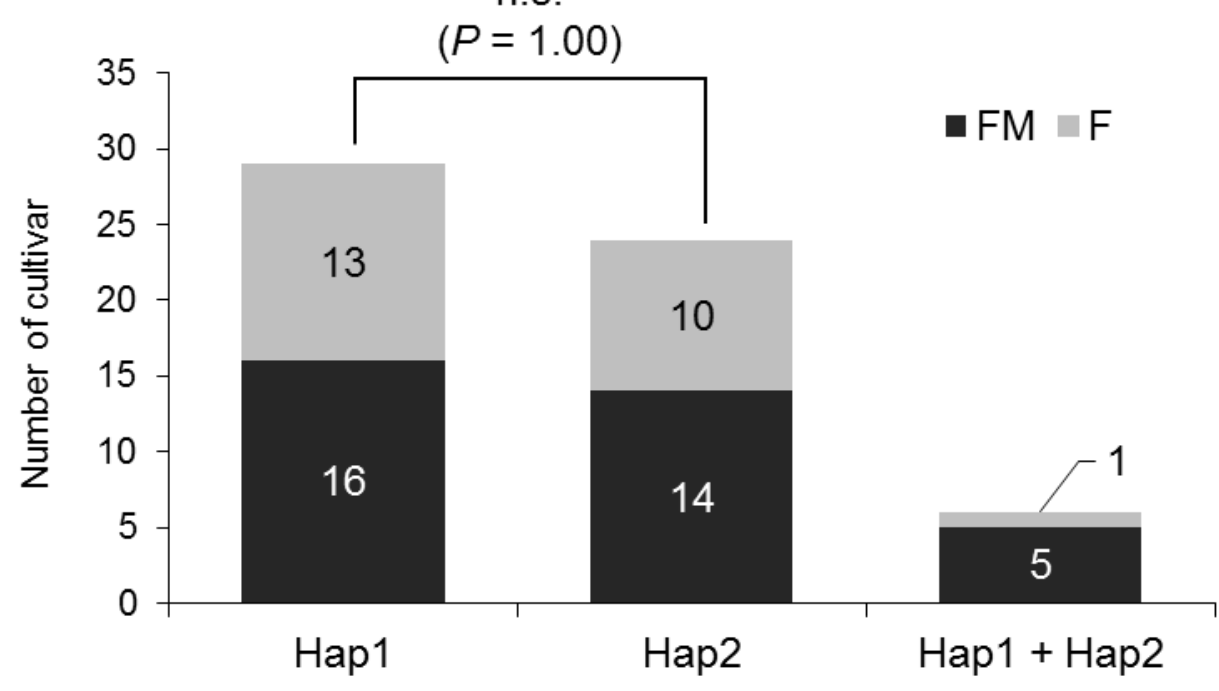

